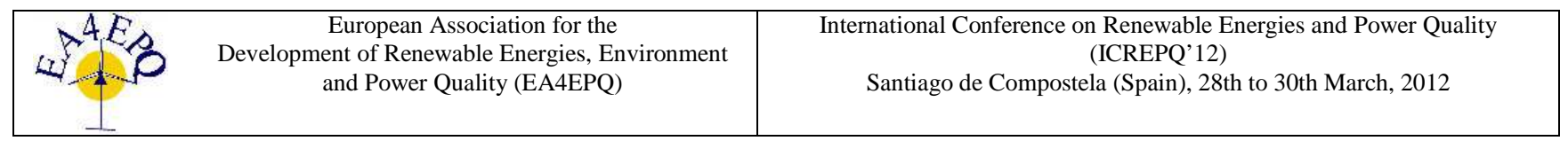

\title{
Rural electrification based on renewable energies. A Review
}

\author{
Olatz Azurza, Iñaki Arranbide and Itziar Zubia \\ ${ }^{1}$ Department of Electrical Engineering \\ EUPD, University of the Basque Country \\ Campus of Gipuzkoa - Plaza Europa 1, 20.018 Donostia-San Sebastián (Spain) \\ Phone/Fax number:+ 34943017 140, e-mail: olatz.azurza@ehu.es, inaki.arrambide@ehu.es, itziar.zubia@ehu.es
}

\begin{abstract}
Rural environments present different electrification needs compared with the urban industrial areas. Those particularities imply rethinking electrification strategies taking into consideration economical, social and environmental aspects. In that respect, renewable distributed generation linked with microgrids presents interesting features for remote or sparsely populated areas. This paper presents the environmental advantages of using renewable generation, and displays a comparative characterization of rural/urban loads, a discussion of the most extended microgrid topologies, a comparative of available storage techniques and a literature review of the main steps in the process of designing a new microgrid.
\end{abstract}

\section{Key words}

Rural electrification, renewable energy, hybrid, microgrid, feasibility.

\section{Introduction}

Access to electricity is still a dream for $20 \%$ of the world's population. Most of them, in fact about $85 \%$, live in rural areas where the extension of utility grid is either complex or expensive [1]. This is due to the features of rural populations, which are remote and disperse, have small incomes and whose electric consumption is low [2]. Moreover, the International Energy Agency (IEA) foresees that if current policies do not change, by 2030 there will still be 1.2 billion people without access to electricity [1]. According to several studies [2], access to electricity does not imply development by itself, unless it is within a context of social development. Nevertheless, it is a steady support to improve the rural populations welfare: it enables enhancement of education and healthcare; it reduces communities' isolation and marginalization, boosts productivity... Subsequently, multiple international aid programs are focusing their efforts on rural electrification: for instance, the UNDP relates electrification to the achievement of 7 out of 8 Milenium Development Goals (MDG) [3]. This means that the world's electricity demand is expected to continue rising.
Additionally, traditional electricity generation technologies (fossil fuels) emit significant greenhouse gases (GHG) into the atmosphere, and hence, contribute to global warming. Besides, problems associated with fossil combustion technologies include acid rain, unequal distribution of resources and resource depletion.

In this scenario, renewable electricity generation technologies provide a satisfactory solution to the two above-mentioned problems: lack of electrification in some regions and non-sustainability of fuel based generation.

This document presents the State of the Art regarding renewable technologies for rural electrification, and the design process, especially for new installations in developing countries.

\section{Rural electrification technologies}

This section describes the most common alternatives in electricity generation attending to the primary source, particular characteristics of load profiles in rural areas and the grid topologies that suit to renewable rural microgrids. Finally, evidences of the maturity level of the presented technologies are given.

\section{A. Primary energy sources and characteristics}

Electricity generation consists in transforming energy from nature into electrical energy. Table I depicts the most common technologies available at the moment: their primary energy source, their renewability and the $\mathrm{CO}_{2}$ emissions rate based on the life cycle of the technology (the $\mathrm{CO}_{2}$ emission rate has been taken as a representative GHG, according to UNFCCC it contributed up to $70 \%$ of global warming in 2006 [4]).

Data from the last column in Table I allows classification of primary sources in three main groups: group (a), shaded in green, presents renewability and very low emission rates (under $20 \mathrm{gCO}_{2} \mathrm{eq} / \mathrm{kWh}$ ); group (b) presents renewability and still low emission rates (under 
$100 \mathrm{gCO}_{2} \mathrm{eq} / \mathrm{kWh}$ ) and group (c), present non-renewability and extremely high emission rates (above 500 $\mathrm{gCO}_{2} \mathrm{eq} / \mathrm{kWh}$ ). It can be concluded that renewable sources are clearly environmentally more efficient.

Table I. - Electricity generation technologies in rural environments

\begin{tabular}{|c|c|c|c|c|}
\hline Technology & $\begin{array}{c}\text { Primary } \\
\text { source }\end{array}$ & $\begin{array}{c}\text { Renewable } \\
\text { (Yes/No) } \\
\text { C/I } \\
\text { Continuous } \\
\text { Intermittent }\end{array}$ & $\begin{array}{c}\text { AC } \\
\text { DC }\end{array}$ & $\begin{array}{c}\text { Emissions [5] } \\
\text { (life cycle } \\
\text { mean } \\
\mathrm{gCO}_{2} \text { eq/kWh) }\end{array}$ \\
\hline \multirow{3}{*}{ Combustion } & Oil & No (C) & AC & 780 \\
\cline { 2 - 5 } & Gas & No (C) & AC & 530 \\
\cline { 2 - 5 } & Coal & No (C) & AC & 1000 \\
\cline { 2 - 5 } Biomass & Yes (C) & AC & 70 \\
\hline PV & Sun & Yes (I) & DC & 56 \\
\hline \multirow{2}{*}{ Wind-farms } & $\begin{array}{c}\text { Mechanical } \\
\text { energy: } \\
\text { water }\end{array}$ & $\begin{array}{c}\text { Yes (C) } \\
\text { energy: } \\
\text { wind }\end{array}$ & AC & 8 \\
\hline
\end{tabular}

Unfortunately, renewable energies are, in most cases, intermittent sources (solar irradiation, wind speed, waves, etc), which is their main disadvantage. For that reason, renewable energies are generally highly dependent on energy storage systems or backed by continuous generation technologies (hydro, biomass or diesel generators). Neveretheless, the combination of different intermittent sources contributes to mitigate this intermittency in supply and it helps to reduce the energy storage need. For example, Figure 1 represents the evolution of solar and wind energy availability in a year [6]. Annual complementary behaviour is clearly deductible from the graph in Figure 1 and leads to designs of hybrid energy systems (HES).

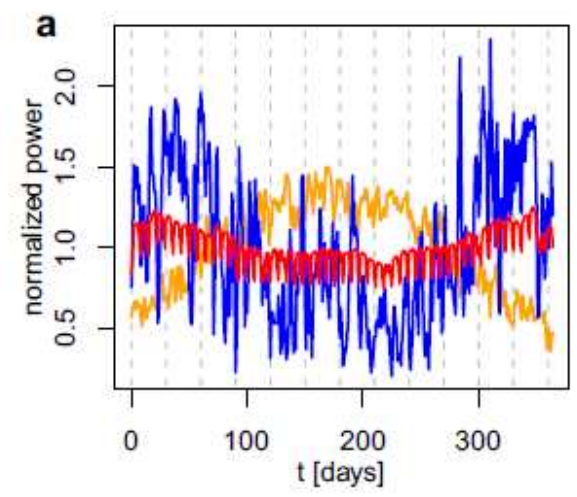

Fig. 1. Normalized (blue) wind power generation, (yellow) solar power generation and (red) load, with spatial aggregation over Europe. (a) One-day resolution over one year.

Another decisive factor for primary sources is the cost of energy $(€ / \mathrm{kWh})$. This parameter depends highly on each region according to local resource availability, energy policies or level of technological advancement [7].

\section{B. Load characterization in rural areas}

A technical characterization of the rural and urban load profiles reveals the following data for feeders - it belongs to a Spanish electric utility: rural load density is up to $0.2-2.5 \mathrm{MVA} / \mathrm{km}^{2}$, whereas a typical city in the outer areas would have load densities in the order of $5 \mathrm{MVA} / \mathrm{km}^{2}$ or less, rising to $60 \mathrm{MVA} / \mathrm{km}^{2}$ or more in the dense central areas [8].

Figures 2 and 3 show, respectively, the apparent hourly load profiles for urban and rural feeders, throughout a year, normalized by their respective annual mean power demands.

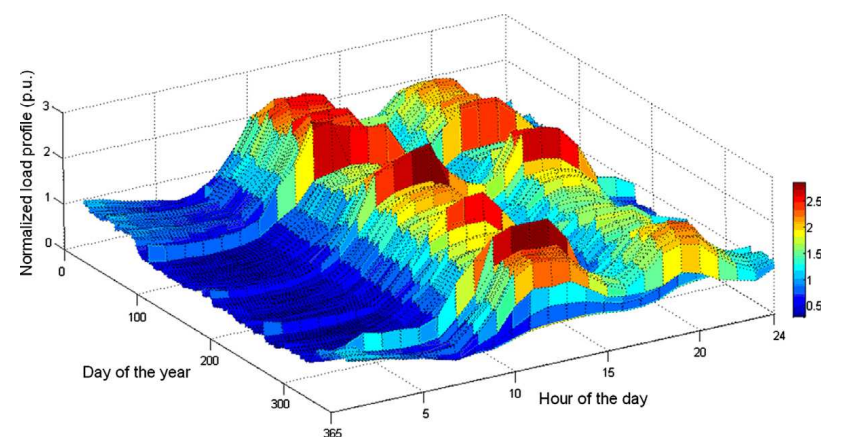

Fig. 2. Normalized hourly load profile throughout a year of a urban feeder [8].

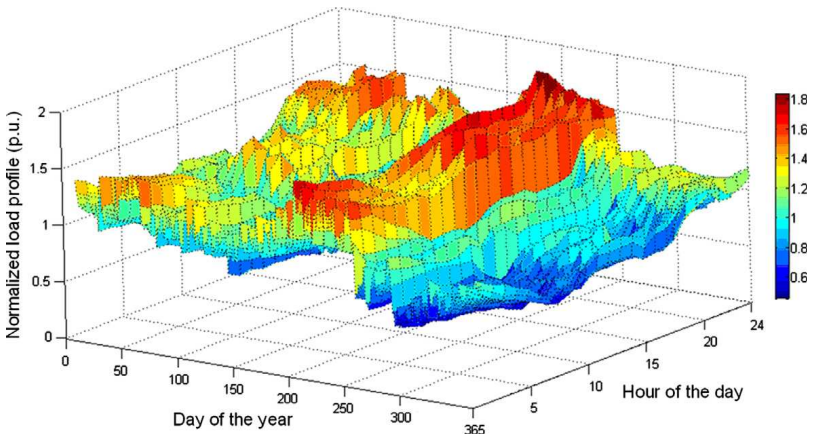

Fig. 3. Normalized hourly load profile throughout a year of a rural feeder [8].

In Figure 2, it is found that the demand during winter is much greater than during summer when many people leave the town for holiday. Only at the beginning of summer, air conditioners $(\mathrm{A} / \mathrm{Cs})$ are important. The hourly shape of the load profile shows a typical load pattern where the main customers are residential and commercial. There is a main peak at noon and a second one, slightly lower, during the evening. The annual hourly peak load reaches 2.86 p.u. at $1 \mathrm{PM}$, while the annual hourly valley load is just 0.26 p.u. at 6 PM [8].

Figure 3 shows that the peak demand occurs in summer due to the use of A/Cs and irrigation. This hourly load profile is smoother than that of the previous one because of the higher rate of rural industrial customers, a very flat load pattern. The annual hourly peak load (1.84 p.u. at 10 $\mathrm{PM})$ happens to be at night time when people are at home. The annual valley load is 0.49 p.u. at $6 \mathrm{AM}$ [8]. 
Taken into consideration the daily national load pattern in Spain (Figure 4), it can be concluded that rural areas present very different electrification needs and are not dominant in the national utility grid.

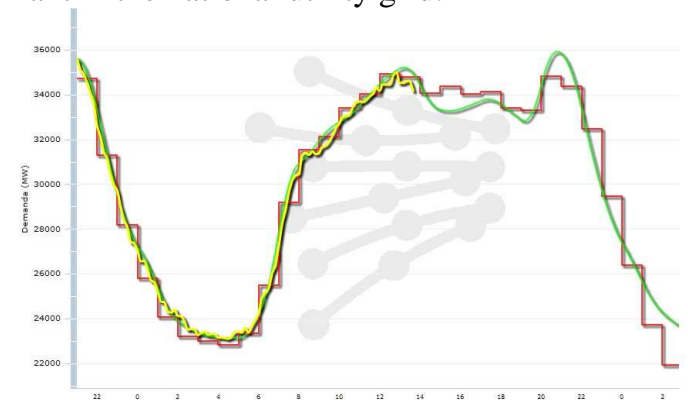

Fig. 4. National daily demand-generation adjusting curve. Spain, $29^{\text {th }}$ September 2011. [9]

Attending to the users, the typical customer mix in urban and rural areas is described in Table II [8]. Industrial demand in rural areas substitutes the commercial demand in urban areas.

Table II. Customer mix breakdown of the tested feeders

\begin{tabular}{|l|c|c|}
\hline Customer class & $\begin{array}{c}\text { Urban } \\
\text { feeder load } \\
\text { composition } \\
(\%)\end{array}$ & $\begin{array}{c}\text { Rural } \\
\text { feeder load } \\
\text { composition } \\
(\%)\end{array}$ \\
\hline MV industrial $(20 \mathrm{kV})$ & 1.13 & 5.56 \\
\hline MV commercial $(20 \mathrm{kV})$ & 4.13 & 3.53 \\
\hline LV industrial (230/400V) & 10.28 & 21.72 \\
\hline $\begin{array}{l}\text { LV commercial } \\
(230 / 400 \mathrm{~V})\end{array}$ & 37.32 & 13.80 \\
\hline LV residential (230/400V) & 47.14 & 55.39 \\
\hline
\end{tabular}

For the characterization of load in developing countries, it is almost impossible to keep track of the habits of lowincome non-electrified rural households. The only data available in poor, rural, non-electrified villages has been been obtained from surveys and questionnaires. No survey, though, has ever been precise enough to produce the necessary data to develop an hourly activity load curve for a particular village. And even if surveys were to pose right questions of that nature, the sample size used in the survey would lead to inaccurate load curves. One of the only methods that would enable accurate rural activity load curves to be developed is (should be?) the recording the time and amount of fuel used during a particular activity, which is an unreasonable task in a big scale [10].

\section{Grid topologies and energy storage techniques}

Electrical grids have historically been built first of all to feed industries and surrounding urban areas and thenassociated with the socialisation of domestic technological revolution- rural areas by means of the extension of utility grids. Generally, due to the economies of scale provided by ever larger generating plants and the (perceived or real) monopoly characteristics of transmission and distribution of electric power centralized generation has been dominant in electric generation schemes [2].
Centralized (conventional) generation is usually placed in locations where the primary energy is easily available, generally, far from the loads. Consequently, large electricity transport and distribution lines and grids have been built. Since it is difficult to store electrical energy in big quantities, electrical grids need to keep the balance between generation and load on real-time (Figure 4). With that aim, national grids hold complex central operation and control units in order to adapt the generation curve to the demand.

Centralised generation presents three main disadvantages, though. First, despite the high quality and evolution of electricity transport technology, this transport-system carries non-negligible leakages (according to IEC these could be between $8 \%$ and $15 \%$ [11]). Second, reliability of grids depends strongly on the meshing degree of the network and this is usually lower in rural areas, where the grid tends to be mostly radial [8]. Hence, in case of failures the transport system turns to be a bottleneck and may affect large zones for considerable periods of time (as it was observed in the north of Spain during the Klaus storm in January 2009, especially in the zone of Girona [9]). Third, extending new branches of transportation systems lays out high resistance from the social and environmental point of view.

In order to avoid above-mentioned weaknesses, and taking into account particularities of rural load characterization (Fig 3), distributed generation (DG) or embedded generation (grids with several and interconnected small generation points) is becoming more usual and is expected to experience a big increase in the following years [12], contributing to the expansion of microgrids (small dimension grids with local generation and local consumer points). Those grids do not need high voltage transportation systems, and hence avoid related losses, and present a higher meshing degree at low voltage. As it happens in the case of national grids, the regulation and balancing of the energy fluxes in microgrids is challenging and currently it's the object of multiple scientific analysis [13].

Generators connected to microgrids tend to be based on diverse primary energy sources (PV, wind, small-hydro) building HES. Particularly the nature of electricity generated (AC or DC) by different technologies (Table I) and the usually short distances linked to the actual innovation in power electronics lead to different topologies in microgrid. Bearing in mind these considerations, three main grid topologies may be distinguished (Figs. 5-7).

The most efficient grid is based on the DC bus (Fig. 6), thanks to the simplicity and robustness of the power electronic management system required (rectifiers and only one inverter), when a unique AC load point and all generating points are proximate to each other. Even then, for each grid configuration a specific efficiency analysis must be done attending particularities of load dispersion, generation distribution, etc. 


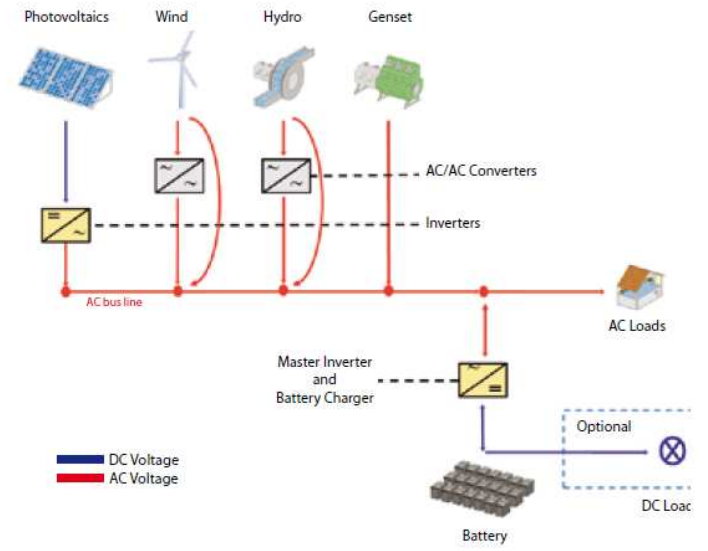

Fig. 5. AC coupled hybrid power system [13]

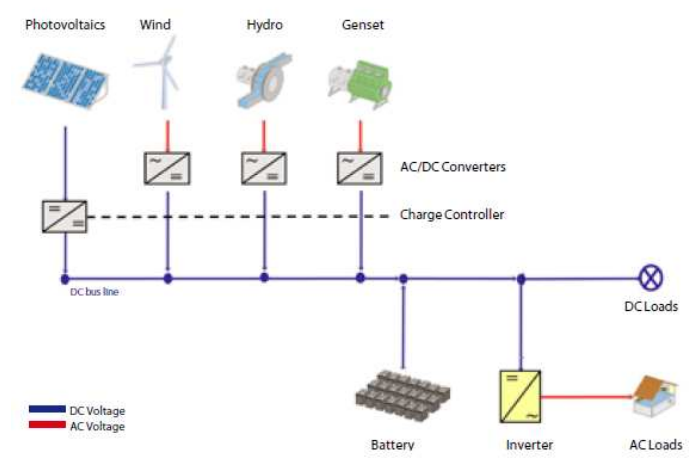

Fig. 6. DC coupled hybrid power system [13]

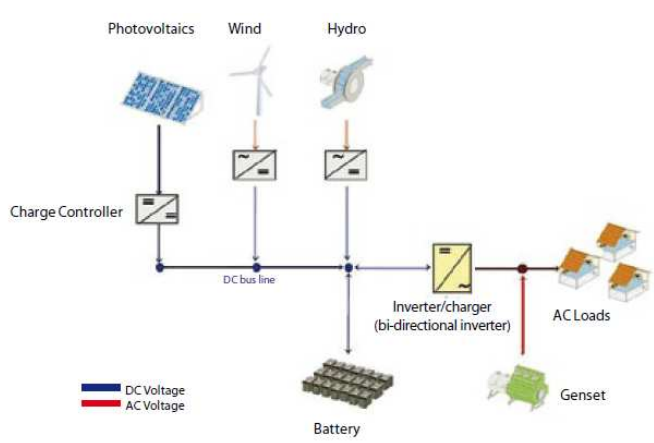

Fig. 7. DC/AC coupled hybrid power system [13]

When working in island configuration without the support of the utility grid, energy storage devices result extremely necessary in microgrid solutions, as the primary source is fluctuant, or at least a continuous back up generation like a diesel engine. Thus, energy storage systems constitute a non-negligible part of DG based microgrids. Commonly energy storage systems in rural electrification include batteries [12]. Flywheels [14] and pump storage hydroelectric (PSH) systems [11] are also quite extended. Fuel cells with hydrogen storage are reaching significant results, as well [15]. Hydrogen storage in salt caverns is still in research phase and only affordable for big projects [16]. Those systems (batteries, flywheels, etc.) typically involve high investment and maintenance costs, however, provide low capacity values [15]; hence, maximum interest is given to storage need reduction techniques [6] or even to the selection of the most economic and sustainable storage systems $[15,17]$.
Table III. Main characteristics of energy storage devices [15]

\begin{tabular}{|c|c|c|c|c|c|c|}
\hline TECHNOLOGIES & \begin{tabular}{|c|} 
Maximum \\
power rating
\end{tabular} & $\begin{array}{l}\text { Discharge } \\
\text { time }\end{array}$ & $\begin{array}{c}\text { Response } \\
\text { time }\end{array}$ & Efficiency & Lifetime & \begin{tabular}{|c|c|c|} 
Energy \\
related cost
\end{tabular} \\
\hline Lead-acid battery & $<50 \mathrm{MW}$ & 1 min-8hours & $<5 \mathrm{~ms}$ & 0.85 & $<10$ years & $200-900 € \mathrm{kWWh}$ \\
\hline $\begin{array}{c}\text { Advanced battery } \\
\mathrm{Zn} / \mathrm{Br}\end{array}$ & $<1 \mathrm{MW}$ & $<4$ hours & $<5 \mathrm{~ms}$ & 0.75 & $>10$ years & $1,500 € / \mathrm{kWh}$ \\
\hline \begin{tabular}{|l} 
Advanced battery \\
Na-NiCl $_{2}$ (ZEBRA)
\end{tabular} & $>24 \mathrm{~kW}$ & $<5$ hours & - & 0.90 & $>14$ years & $600 \epsilon / \mathrm{kWh}$ \\
\hline SMES & $10 \mathrm{~kW}-10 \mathrm{MW}$ & $1-30 \min$ & $<5 \mathrm{~ms}$ & 0.95 & 30 years & $300-2,000 \in \mathrm{kWh}$ \\
\hline $\begin{array}{l}\text { Flywheel: } \\
\text { Low speed }\end{array}$ & $<1,650 \mathrm{~kW}$ & $3-120 \mathrm{sec}$ & $<20 \mathrm{~ms}$ & 0.90 & 20 years & $1,500 € / k W h$ \\
\hline $\begin{array}{l}\text { Flywheel: } \\
\text { High speed }\end{array}$ & $<750 \mathrm{~kW}$ & $<1$ hour & $<20 \mathrm{~ms}$ & 0.93 & 20 years & $20,000 \in \mathrm{EWWh}$ \\
\hline Supercapacitors & $<100 \mathrm{~kW}$ & $10 \mathrm{sec}$ & $<5 \mathrm{~ms}$ & 0.90 & $>10^{6}$ cycles & $10,000 \in \mathrm{kWWh}$ \\
\hline
\end{tabular}

Table III displays lead-acid batteries as the most economic solution for storage with large discharge times and a wide variety of rated powers. Even that, Figure 8 shows the significant advantages of PSH both from the point of view of rated power and discharge time (PSH has also been used within the management of conventional grids in areas with important hydropower systems) [17].

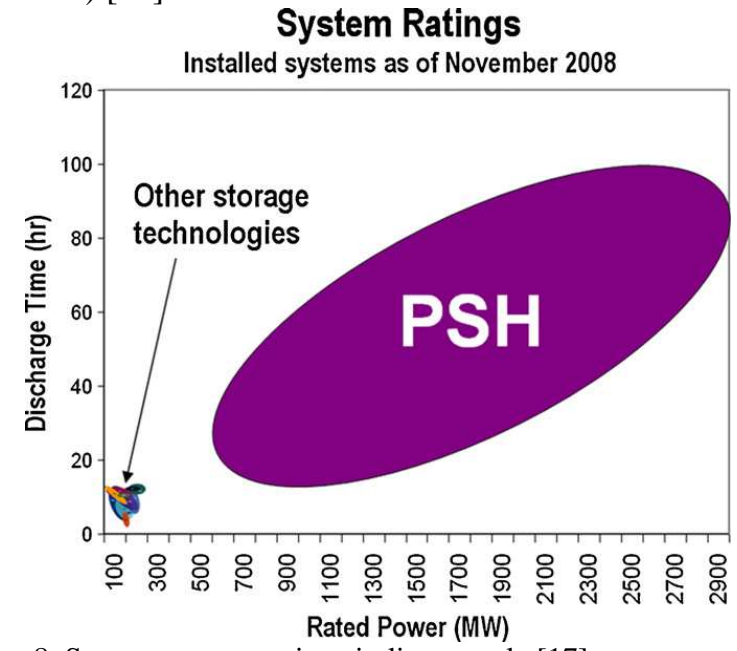

Fig. 8. Storage system ratings in linear scale [17]

\section{Maturity level of renewable generation and micro-grid industry for rural areas}

Too often, renewable sources are still considered to bein a developing stage. Yet, important industry clusters focus their business on renewable energy systems. Two kinds of evidence are provided in this paper: the level of standardisation, on one hand, and the activity clusters related to renewable rural electrification on the other [12].

Any renewable based program or project targeting sustainability should follow a minimal set of standards in order to ensure that the best products are installed and used. By imposing a quality remit on an implementation programme, the likelihood of a project's success can be substantially enhanced. It is generally acknowledged that recognised standards lead to an increased quality of a given product [12].

Table IV collects a list of quality standards related to renewable generation and microgrids, according to the ARE (Alliance for Rural Electrification) . ARE is a global network of innovative and dedicated professionals 
to promote and provide technological and financial solutions for rural electrification [12].

Table IV. - International standards for small standalone PV systems, components, Wind Turbines and Microgrids

\begin{tabular}{|c|c|}
\hline \multirow{2}{*}{ Panels } & IEC 61215 Ed. 2.0 \\
\hline & IEC 61646 Ed. 1.0 \\
\hline \multirow{6}{*}{ Charge Controllers } & IEC 62509 Ed.1 \\
\hline & IEC 62109 \\
\hline & IEC 62093 Ed. 1.0 \\
\hline & IEC CISPR 11:1990 \\
\hline & IEC 61000-4:1995 \\
\hline & PV GAP, PVRS6A \\
\hline \multirow{6}{*}{ Inverters } & IEC 61683 Ed. 2.0 \\
\hline & IEC 62109 \\
\hline & IEC 62093 Ed. 1.0 \\
\hline & IEC CISPR 11:1990 \\
\hline & IEC 61000-4:1995 \\
\hline & PV GAP, PVRS 8A \\
\hline \multirow{3}{*}{ Wind Turbines } & IEC 61400-2 \\
\hline & IEC 61400-11 \\
\hline & IEC 61400-12 \\
\hline $\begin{array}{l}\text { Hydraulic turbines, storage } \\
\text { pumps and pump turbines - } \\
\text { Model acceptance tests }\end{array}$ & IEC 60041 (1991-11) \\
\hline $\begin{array}{l}\text { Hydro sector with mini grids: } \\
\text { Recommendations for small } \\
\text { renewable energy and hybrid } \\
\text { systems for rural } \\
\text { electrification }\end{array}$ & IEC/TS 62257 \\
\hline
\end{tabular}

Other known and followed standards are designed by MCS (UK, overall certification including factory inspection) and AWEA (American Wind Energy Association).

\section{Design process of a renewable microgrid}

The following section describes the factors to be taken into account before planning a new electrification solution or an improving proposal in a rural environment.

\section{A. Technical aspects of the design}

Once selected a population or a rural area to electrify, a consumption assessment must be done in terms of peak power and amount of energy needed in a yearly basis: the available data quality varies considerably from a rural zone in a developed country [8], to that one in a developing country [10]. In parallel, an assessment of local renewable energy resources must be done for the selected area in terms of PV, wind, biomass and micro-hydro. This analysis may be done with available satellite images or databases in a preliminary stage and validated with local measurements $[12,18,19]$. Third, and depending on the interests of users, the energy control and storage strategy has to be defined: the more reliable is required to be the supply the larger must be the storage or generation, and hence more expensive will become the energy unit [20, 13]. Once the load characterization is done, the assessment of renewable resources is available and the control strategy is adopted, the primary source mix definition must be made. This study is usually performed versus a cost optimization function modelling and gives as a result the size of each generating technology [21].
Despite the advantages of DG, it requires complex design, planning and control optimization algorithms. Being aware of the number of research papers that use optimization methods to solve renewable energy, it can be concluded that related literature has increased significantly in recent years, especially on wind and solar energy systems [22, 23].

Finally, the expected system performance has to be checked in permanent regimes as well as in case of failures by means of electrical simulation using Matlab Simulink or EMTP/ATP, for instance [14, 24, 25].

\section{B. Economic feasibility, social and environmental impact}

From the economic point of view renewable resources present the advantage of no fossil fuel dependency, but the disadvantage of higher installation investment requirements. As the technology evolutes, though, the cost of equipment decreases as the price of fossil fuels continues reaching new historical summits. Therefore, economical analyses must be made taking into consideration the life-cycle span of the system. This is done by taking a base case and analysing the sensitivity of the costs to several parameter changes in future: fuel cost, equipment reliability, energy demand rate, evolution of technology's price, etc [26]. The mix of renewable energy chosen has a deep impact in the cost of energy, as each technology presents different cost per $\mathrm{kWh}$ : for large energy quantities, the most expensive energy source is usually the PV [21].

Along the economical analyses, environmental impact studies must be carried out. With that aim, life cycle assessment (LCA) is the most commonly used method to assess environmental impact of different technologies, based on the international standards ISO 14040 [27]. Results of this kind of study have been analysed in section 2.A of the present paper. Other studies can be obtained from [28, 29, 30].

Social impact of the system is another parameter to keep in mind: local labour maintenance skills, local employ generation, related local business profits, final usage given to the supply etc. Generally, the more backed the project by the local community, the more success probabilities it has [12].

\section{Conclusions}

It has been concluded that rural electrification presents different load patterns in relation to that of urban loads in terms of the daily variation expected and the yearly variation: rural patterns are smoother. Besides, in case of remote areas that present small incomes (common parameters for most rural areas), the extension of utility grids is not feasible and the total dependence on imported fossil fuels is economically unaffordable, fuel transport costs become prohibitive. Moreover, the use of fossil fuels carry associated contrasted severe environmental impacts. 
In this outline, renewable energy resources are an interesting solution, especially integrated in microgrids. Difficulties inherent to this kind of electrical systems are the intermittency in supply and consequent storage needs. This leads to the design of tailored grid control strategies. Projects to be faced in these parameters need to comply with international quality standards in order to improve the likelihood of the project's success.

Additionally, preliminary studies in terms of economical feasibility social- and environmental-impact assessments have to be done. From the technological point of view local load demand and renewable resource assessments have to be done, as well as a tailored microgrid design. Finally, optimization analyses have to be done in order to install the most interesting solution out of the available ones.

To sum up, rural electrification based on renewable energies in developing countries promises a cleaner, cheaper and more democratic way of improving the quality standard of an important section of the world's population.

\section{References}

[1] IEA, World Energy Outlook 2010. www.worldenergyoutlook.org/

[2] H. Zerriffi, Rural Electrification: Strategies for Distributed Generation, Springer Science+Business Media B.V. (2011) pp.1-3

[3] UNDP's Environment and Energy Group, “Accelerating Progress Towards the Millennium Developm ent Goals UNDP's Work in Environment and Sustainable Development" 2010 Millennium Development Goals Review Summit, 2010.

[4] B. Moselle, J. Padilla, R. Schmalensee, Electricidad verde, Marcial Pons, Madrid-Barcelona-Buenos Aires, 2010.

[5] D. Weisser, "A guide to life-cycle greenhouse gas (GHG) emissions from electric supply technologies", Elsevier, Energy 32 (2007) 1543-1559.

[6] D. Heide, M. Greiner, L. von Bremen, C. Hoffmann, "Reduced storage and balancing needs in a fully renewable European power system with excess wind and solar power generation", Elsevier, Renewable Energy 36 (2011), 25152523.

[7] A. Chaurey, T. C. Kandpal, "Assessment and evaluation of PV based decentralized rural electrification: An overview", Elsevier, Renewable and Sustainable Energy Reviews 14 (2010) 2266-2278

[8] J.C. Hernández, A. Medina, F. Jurado, "Impact comparison of PV system integration into rural and urban feeders", Elsevier, Energy Conversion and Management 49 (2008) pp. 1747-1765.

[9] Red Eléctrica Española, www.ree.es.

[10] N Cross and C. T. Gaunt, "Application of Rural Residential Hourly Load Curves in Energy Modelling", in IEEE Bologna Power Tech. Conference, 2003.

[11] Z. Glasnovic, J. Margeta, "Vision of total renewable electricity scenario", Elsevier, Renewable and Sustainable Energy Reviews, 15 (2011), pp. 1873-1884

[12] Alliance for Rural Electrification, Rural electrification with renewable energy: Technologies, quality standards and business models, (2011), www.ruralelec.org

[13] R. Zamora, A. K. Srivastava, "Controls for microgrids with storage: Review, challenges, and research needs", Elsevier, Renewable and Sustainable Energy Reviews, 14 (2010) 2009-2018
[14] G. N. Prodromidis, F. A. Coutelieris, "Simulations of economical and technical feasibility of battery and flywheel hybrid energy storage systems in autonomous projects", Elsevier, Renewable Energy 39 (2011), pp. 1-5.

[15] J.I. San Martín, I. Zamora, J. J. San Martín, V. Aperribay, P. Eguia, "Hybrid fuel cells technologies for electrical microgrids", Elsevier, Electric Power Systems Research, 80 (2010), pp. 993-1005.

[16] S. Donadei, F. Crotogino, "Energy storage in salt caverns today and tomorrow", 9th World salt symposium, Beijing, China; 04-09 September 2009.

[17] Glasnovic Z, Margeta J. Sustainable electric power system: is it possible? Case-study: Croatia. J Energy Eng 2010;36:103-13.

[18] I. Nygaard, K. Rasmussen, J. Badger, T. T. Nielsen, L. B. Hansen,S. Stisen, S. Larsen, A. Mariko, I. Togola, "Using modeling, satellite images and existing global datasets for rapid preliminary assessments of renewable energy resources: The case of Mali”, Elsevier, Renewable and Sustainable Energy Reviews, 14 (2010), pp. 2359-2371

[19] S. K. Lohan, J. Dixit, S. Modasir, M. Ishaq, "Resource potential and scope of utilization of renewable energy in Jammu and Kashmir, India", Elsevier, Renewable Energy 39 (2012), pp. 24-29.

[20] A.B. Kanase-Patil, R.P. Saini, M.P. Sharma, "Integrated renewable energy systems for off grid rural electrification of remote area", Elsevier, Renewable Energy 35 (2010), pp. 1342-1349.

[21] A.B. Kanase-Patil, R.P. Saini, M.P. Sharma, "Sizing of integrated renewable energy system based on load profiles and reliability index for the state of Uttarakhand in India”, Elsevier, Renewable Energy 36 (2011), pp. 2809-2821.

[22] R. Baños, F. Manzano-Agugliaro, F.G. Montoya, C. Gil, A. Alcayde, J. Gomez, "Optimization methods applied to renewable and sustainable energy: A review", Elsevier, Renewable and Sustainable Energy Reviews 15 (2011), pp. 1753-1766.

[23] L. Ferrer-Martí, R. Pastor, G. M. Capó, E. Velo, "Optimizing microwind rural electrification projects. A case study in Peru", Springer, Journal of Global Optimization 50 (2011), pp. 127-143

[24] A. Gupta, R.P. Saini, M.P. Sharma, ”Modelling of hybrid energy systemd. Part III: Case study with simulation results", Elsevier, Renewable Energy 36 (2011) 474-481

[25] L.Ye, H. B. Sun , X. R. Song, L. C. Li, "Dynamic modeling of a hybrid wind/solar/hydro microgrid in EMTP/ATP", Elsevier, Renewable Energy 39 (2012) 96106

[26] M. Kolhe, S. Kolhe, J.C. Joshi "Economic viability of stand-alone solar photovoltaic system in comparison with diesel-powered system for India”, Elsevier, Energy Economics 24 (2002).pp. 155-165.

[27] ISO 14040. Environmental management - life cycle assessment - principles and framework, <http://www.iso.org/iso/home.htm>; 2006.

[28] E. Santoyo-Castelazo, H. Gujba and A. Azapagic, "Life cycle assessment of electricity generation in Mexico", Elsevier, Energy 36 (2011) , pp. 1488-1499

[29] A. Pascale, T. Urmee, A. Moore, "Life cycle assessment of a community hydroelectric power system in rural Thailand", Elsevier, Renewable Energy 36 (2011), pp.2799-2808.

[30] R. Kabir, B. Rooke, M. Dassanayake, B. Fleck, "Comparative life cycle energy, emission, and economic analysis of $100 \mathrm{~kW}$ nameplate wind power generation", Elsevier, Renewable Energy 37 (2012), pp 133-141. 